\title{
THE EFFECT OF WORK SATISFACTION AND WORK STRESS ON EMPLOYEES' TURNOVER INTENTION IN PT. TELKOM INDONESIA YOGYAKARTA
}

\author{
Ani Muttaqiyathun \\ Faculty of Economics and Business, Ahmad Dahlan University, Yogyakarta \\ animtq@mgm.uad.ac.id \\ Dita Ayu Rosita \\ Faculty of Economics and Business, Ahmad Dahlan University, Yogyakarta \\ ditaayurosita16@gmail.com
}

Received: February, 2019; Accepted: April, 2019; Published: Mar, 2020

DOI: https://doi.org/10.24123/jmb.v19i1

\begin{abstract}
This study aims to determine the effect of job satisfaction and work stress on turnover intention. The population in this study were 104 employees who worked in the company named PT. Telkom Indonesia Yogyakarta. The results are based on saturated sampling techniques obtained 92 samples as respondents. The type of data used is primary data obtained from questionnaires answered directly by respondents who in this study employees of PT. Telkom Indonesia Yogyakarta

Based on the results of multiple linear regression analysis with a significance level of $5 \%$, it can be concluded that job satisfaction has a significant negative effect on employee turnover intention and work stress have a significant positive effect on employee turnover intention of PT. Telkom Indonesia Yogyakarta. Job satisfaction and work stress simultaneously influence turnover intention of PT. Telkom Indonesia Yogyakarta.
\end{abstract}

Keywords: job satisfaction, turnover intention, work stress

\begin{abstract}
Abstak
Penelitian ini bertujuan untuk mengetahui pengaruh kepuasan kerja dan stres kerja terhadap turnover intention. Populasi dalam penelitian ini adalah 104 karyawan yang bekerja di perusahaan bernama PT. Telkom Indonesia Yogyakarta. Hasilnya didasarkan pada teknik sampling jenuh yang diperoleh 92 sampel sebagai responden. Jenis data yang digunakan adalah data primer yang diperoleh dari kuesioner yang dijawab langsung oleh responden yang dalam penelitian ini karyawan PT. Telkom Indonesia Yogyakarta. Berdasarkan hasil analisis regresi linier berganda dengan taraf signifikansi 5\%, dapat disimpulkan bahwa kepuasan kerja berpengaruh negatif signifikan terhadap intensi turnover karyawan dan stres kerja berpengaruh positif signifikan terhadap intensi turnover karyawan PT. Telkom Indonesia Yogyakarta. Kepuasan kerja dan stres kerja secara simultan mempengaruhi intensi turnover PT. Telkom Indonesia Yogyakarta.

Indonesia.
\end{abstract}

Kata Kunci: kepuasan kerja, turnover, stress kerja 


\section{INTRODUCTION}

Successful companies are definitely supported by skillful Human Resources (HR). Human resources in a company have a significant contribution in realizing the goals of the company itself. Human Resources is a very influential part of the process of coordinating and integrating activities within the company. A good and successful company can be seen from a low number of turnovers. The lower the amount of turnover, the company can be declared as successful in terms of prospering employees.

According to Nelwan (2008) turnover intention is something that make employees want to move from the company where they worked before. Turnover intention is basically the desire to leave the company. Mobley (1986) mentions several factors that cause Turnover Intention such as individual characteristics which include age, education and marital status. The work environment consists of the physical environment in the form of buildings, temperature conditions, and the location of work and the social environment in the form of social culture and quality of work life. Job satisfaction cobers satisfaction with salary and promotion, satisfaction with colleagues and satisfaction with work and work content. In addition, there are organizational commitment factors that are one of the causes of turnover intention.

Employee job satisfaction is one of the things that is very complex for the company and is one of the important aspects for both employees and performance. Employee job satisfaction greatly affects the performance of employees to stay with employees or even look for other companies. Luthans (2006) states indicators that can be used to assess job satisfaction including the payment of salaries, work performed, co-workers, promotion and so forth. Each individual has a different level of satisfaction according to themselves. The more aspects that are in accordance with individual desires, the higher the level of job satisfaction. In addition to turnover intention, job satisfaction can also be influenced by work stress.

Stress generally occurs as a result of someone accepting an unexpected condition from their environment, giving rise to certain reactions. According to Handoko (2001) stress as a condition of tension can affect emotions, the process of thinking and one's condition. There are various factors that influence job stress, Martoyo (2007) says that there are six factors which cause stress to work employees in an organization, including excessive workload, pressure, supervision quality, unsafe political climate, feedback about implementation of inadequate work and insufficient authority to carry out responsibilities.

PT. Telkom Indonesia is a company worked on the field of technology services. This company has many targets in its efforts to provide customer satisfaction, so the company is always looking for new innovations in its business. The more technology develops and the many desires and needs of consumers, the more companies and employees have to do in PT. Telkom Indonesia. In this case, the company is required to always find new ideas that are able to maintain the success of this company.

PT. Telkom Indonesia is always active in carrying out promotions and continues to develop its products, so that the development can lead to the emergence of very dense and continuous jobs, As the effect, it is worried that it will bring negative impacts on employees. Based on recapitulation, employees' absence without reasons PT Telkom Indonesia Bandung from 2009 - 2013 was 15\%. Therefore, researchers will conduct a research with the title " The Effect of Work Satisfaction and Work Stress on Employees' Turnover Intention in Pt. Telkom Indonesia Yogyakarta".

According to Mas'ud (2002), job satisfaction is a positive attitude towards work in a person. Basically, job satisfaction is an individual thing. Each individual will have a different level of satisfaction according to the value system that applies to him. Usually, 
people will feel satisfied with work that has been or is being carried out, if what is done is considered to have met expectations, in accordance with the purpose of work. If someone craves for something, then the person concerned has an expectation and it motivates to take action towards achieving the goals. If these expectations are met, satisfaction will be felt.

Based on Martoyo (2007), job satisfaction is the emotional state of employees whether there is a meeting point between the value of employee retribution from a company / organization and the level of remuneration that is desired by the employee or not. Job satisfaction also affects employee absenteeism, turnover, morale, complaints and other personnel problems. Job satisfaction can also affect the level of productivity of employees in an organization or company.

Handoko (2001) argues that stress is a condition of tension that affects emotions, the process of thinking and one's condition. High level of stress can threaten a person's ability to deal with environmental conditions. According to Dewi et al (2014) stress can occur in almost all jobs, both the level of leadership and executors. Job stress is not only caused by fellow co-workers, but can also be caused by the environment and other factors that are different for each individual. Rivai and Dedy (2012) views job stress as a condition of tension arising from the inability of employees to face changes in the work environment.

According to Issa et. al (2013) instead of Dewi et al (201) Turnover intention is the intention to leave the company voluntarily, which can affect the status of the company and will definitely affect employee productivity. Dubas and Nijhawan (2007) instead of Dewi et al (2014) state that turnover has a negative effect on companies because it causes additional costs that are detrimental.

\section{Research Model}

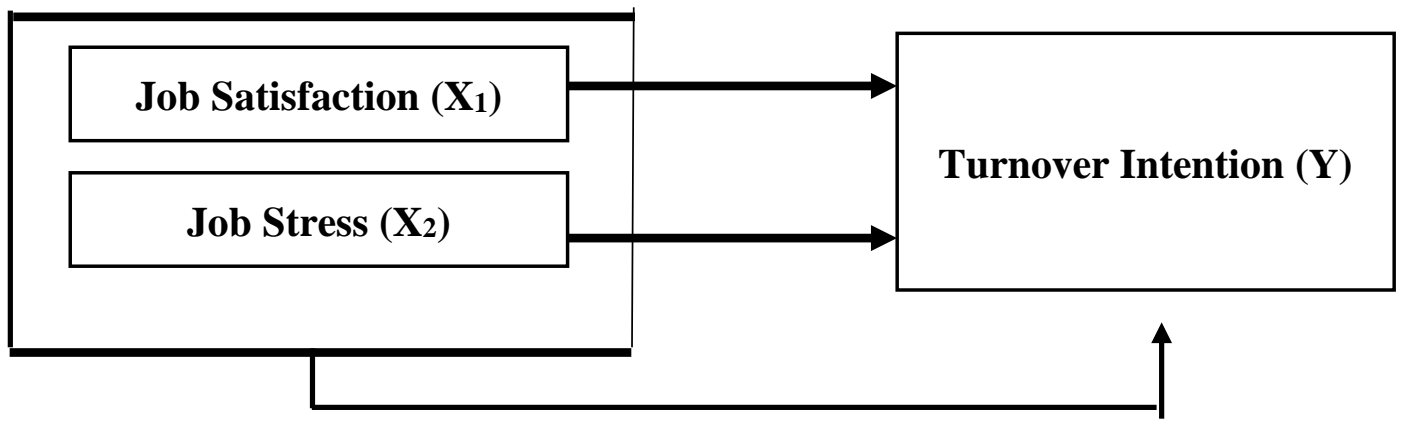

Figure 1: Research Model

$H$ 1: Job satisfaction has a significant effect on turnover Intention

$\mathrm{H}$ 2: Job stress has a significant effect on turnover intention

H 3: Job satisfaction and work stress have a significant effect on turnover intention

\section{RESEARCH METHODS}

Population is the subject of research. According to Sugiyono (2015), the population is a generalized region consisting of object or subject with certain qualities and characteristics set by the researcher to be studied and then to be concluded. In this study, the population used was employees of the company PT. Telekomunikasi Indonesia Yogyakarta Jl. Yos Sudarso no. 9, Gondokusuman, Yogyakarta City, totaling 104 employees.

Sugiyono (2015) states sample is part of the number and characteristic possessed by the population. Samples are used if the population is too large and 
researchers are unlikely to learn everything in the population.

Sampling in this study was determined using a saturated sampling technique. According to Sugiyono (2015), saturated side is a sampling technique if all members of the population are used as samples. In this study, the sample was all employees of the company PT. Telkom Indonesia Yogyakarta, amounting to 104 employees.

The type of data used was primary data. Primary data is data obtained from direct research results. Whereas, according to Sangadji and Sopiah (2010) primary data is data collected by the researchers directly from the first source. The primary data collection method used in this study was a questionnaire with distribution method.

This study used operational definitions and measurement variables with their respective indicators as presented in the following table:

Table 1. Operational Definitions and Indicators

\begin{tabular}{|c|c|}
\hline Operational Definition & Indicator \\
\hline $\begin{array}{l}\text { Turnover Intention is the tendency or } \\
\text { intention of employees to stop working } \\
\text { on their own volition. }\end{array}$ & $\begin{array}{l}\text { 1. The thought of leaving the } \\
\text { organization } \\
\text { 2. The desire for a new job } \\
\text { 3. The desire to leave the } \\
\text { organization } \\
\text { (Mobley, 1986) }\end{array}$ \\
\hline Job Satisfaction is the result of & 1. The work itself \\
\hline employees' perceptions of how well their & 2. Payment \\
\hline $\begin{array}{l}\text { work provides things that are considered } \\
\text { important (Luthans, 2006) }\end{array}$ & $\begin{array}{l}\text { 3. Opportunity for promotion } \\
\text { 4. Work relationship } \\
\text { 5. Supervision }\end{array}$ \\
\hline Job stress is a feeling of stress & 1. Workload \\
\hline experienced by employees in facing the & 2. Working time \\
\hline work (Luthans, 2006) & $\begin{array}{l}\text { 3. Feedback } \\
\text { 4. Responsible }\end{array}$ \\
\hline
\end{tabular}

The data analysis technique used in this study was an instrument test which includes validity and reliability testing. Hypothesis tested by using multiple linear regression analysis, partial test ( $t$ test), simultaneous test ( $F$ test), and coefficient of determination with a significance level of $5 \%$.

\section{RESULT AND DISCUSSIONS}

Table 1. Validity Test Results

\begin{tabular}{llll}
\hline & Code & Value & Information \\
\hline & X1_1 & 0.498 & Valid \\
& X1_4 & 0.722 & Valid \\
& X1_5 & 0.647 & Valid \\
& X1_6 & 0.785 & Valid \\
& X1_9 & 0.524 & Valid \\
Job Satisfaction $\left(X_{1}\right)$ & X1_10 & 0.604 & Valid \\
& X1_11 & 0.677 & Valid \\
& X1_12 & 0.646 & Valid \\
& X1_13 & 0.683 & Valid \\
& X1_14 & 0.779 & Valid \\
& X1_15 & 0.671 & Valid \\
& X2_2 & 0.820 & Valid
\end{tabular}




\begin{tabular}{llll} 
Job Stress $\left(\mathrm{X}_{2}\right)$ & X2_3 & 0.814 & Valid \\
& X2_4 & 0.406 & Valid \\
& X2_6 & 0.633 & Valid \\
& Y_3 & 0.578 & Valid \\
& Y_4 & 0.659 & Valid \\
Turnover Intention $(Y)$ Y_5 & 0.422 & Valid \\
& Y_6 & 0.699 & Valid \\
& Y_7 & 0.704 & Valid \\
& Y_8 & 0.911 & Valid \\
& Y_9 & 0.680 & Valid \\
\hline
\end{tabular}

From the table above, it could be seen that each variable indicator is valid. So, the conclusion is these indicators could be used to measure research variables.

Table 2. Reliability Test Results

\begin{tabular}{lcl}
\hline \multicolumn{1}{c}{ Variable } & Cronbach Alpha value & \multicolumn{1}{c}{ Information } \\
\hline Job Satisfaction $(\mathrm{X} 1)$ & 0.878 & Reliable \\
Job Stress $(\mathrm{X} 2)$ & 0.657 & Reliable \\
Turnover Intention $(\mathrm{Y})$ & 0.820 & Reliable \\
\hline
\end{tabular}

Source: data processed

The value of Cronbach Alpha for all variables is greater than 0.6. From the existing provisions, all variables used in the study are reliable. Based on the results of multiple linear regression test analysis, the regression equation can be made as follows:

$\mathrm{Y}=4,906-0,949 \mathrm{X} 1+0,569 \times 2+\mathrm{e}$

The regression equation above can be explained that: (1) The constant of 4.906 shows that if job satisfaction and work stress do not exist, then intention turnover is 4.906. (2) Job Satisfaction regression (X1) value of -0.949 and negative, this states that if there is an increase in job satisfaction (X1), then turnover intention ( $Y$ ) will decrease by $-0,949$, assuming other variables remain. The results of this study indicate that if job satisfaction (X1) increasing, it causes a decrease in turnover intention (Y). (3) Job stress. The value of work stress regression coefficient (X2) is 0.569 and it is positive. It states that there is an increase in work stress (X2), then turnover intention $(Y)$ will increase by 0.569 , assuming other variables remain. The results of this study indicate that if work stress $(X 2)$ increases, it causes an increase in turnover intention $(Y)$.

Table 3. T Test Analysis Results

\begin{tabular}{lcccc}
\hline \multicolumn{1}{c}{ Variable } & t-table & $\begin{array}{c}\text { Significance } \\
\text { value }\end{array}$ & Information & Decision \\
\hline Job satisfaction & $-5,421$ & 0,000 & Significant & Hypothesis is supported \\
Work stress & 5,322 & 0,000 & Significant & Hypothesis is supported \\
\hline Source:
\end{tabular}

Source: data processed

(a) The result of partial test which influence job satisfaction on turnover intention shows the significant level of 0.000 which indicates influence job satisfaction negative and significant for turnover intention. (b) Partial test results influence work 
stress on turnover intention amounted to 5,322, with a significant level of 0.000 which indicates the stress of work and significant positive effect on turnover intention.

Table 4. F Test Results

\begin{tabular}{llccc}
\hline \multicolumn{1}{c}{ Variable } & F-table & $\begin{array}{c}\text { Significance } \\
\text { value }\end{array}$ & Information & Decision \\
\hline Job satisfaction & 70,485 & 0,000 & Significant & Hypothesis is supported \\
\& work stress & & & & \\
\hline \multicolumn{2}{l}{ Source: data processed }
\end{tabular}

Based on the results of multiple linear regression tests, the value of $f$ arithmetic is 70.485 with a probability of $0.000<0.05$, thus the third hypothesis in this study is accepted. This means that $\mathrm{H} 3$ is accepted where there is a significant influence between job satisfaction and work stress to turnover intention.

Table 5. The coefficient of determination test results

\begin{tabular}{ccc}
\hline $\mathrm{R}$ & $\mathrm{R}$ Square & Adjusted R Square \\
\hline 0.783 & 0.613 & 0.604 \\
\hline
\end{tabular}

Source: data processed

Based on the results, the value of $R 2$ is 0.613 . It means that the variables chosen on the independent variable (job satisfaction and work stress) can explain the variation of the dependent variable (turnover intention) with a contribution of $61.3 \%$ while the remaining $38.7 \%$ is explained by another variable not included in this study.

(1) The Effect of Job Satisfaction on Turnover Intention. Based on the results, the calculation obtained a significance value of $0,000<$ from alpha 0,05 and the value of $t$ count $-5,421$. So that, job satisfaction (X1) has a significant negative effect on turnover intention (Y). The results of this study can prove that workforce has a significant negative effect on turnover intention. Then, job satisfaction can determine or influence turnover intention. This can happen because employees who are satisfied with their performance or work will reduce the risk of turnover intention or the desire of employees to quit their jobs. High job satisfaction can generate employee loyalty, the higher employee loyalty, the employees will stay with the company where they work today. Because employees feel their needs have been met properly, both in the form of financial and non-financial needs, employees feel their needs by management or coworkers are sufficiently fulfilled so that employees feel satisfied with their jobs so that there is no desire to leave their current jobs or leave their current company. The results are consistent with the results of the study Waspodo, Handy \& Paramita (2013), and Syahronica (2015) all of them concluded that job satisfaction negatively affect turnover intention. Only the research concluded that job satisfaction did not significantly influence turnover intention. (2). Effect of Job Stress on Turnover Intention. The result shows that the calculation obtained a significance value of 0,000 $<$ from alpha 0,05 and the value of $t$ arithmetic 5,322. In other words, work stress (X2) has a significant positive effect on the work performance of $w(Y)$. The results of this research can prove that work stress has a positive and significant effect on turnover intention. Hence, job stress can determine or influence turnover intention. The work stress experienced by each employee varies greatly in the level of each individual, causing different effects. The impact of stress experienced by employees has positive and negative impacts. However, in this study researchers only discussed the negative effects of work stress. So, from these results it can be concluded that if work stress is 
experienced by a high employee, then the level of desire of employees to leave the company or turnover intention will also be high. Whereas, if the work stress level is low then the employee's desire to leave the company or turnover intention will also be low. The results of this study are consistent with the results of Waspodo's, Handayani \& Paramita (2013), Syahronica (2015) research, where the conclusion is that work stress has a significant positive effect on turnover intention. (3) Effect of Job Satisfaction and Job Stress on Turnover Intention. Based on the results of the calculation obtained, the results of the $F$ test (simultaneous test) independent variables job satisfaction and work stress together have a significant effect on the dependent variable (turnover intention). This is proved by the significance of $0,000<$ from alpha 0.05 , so the statement shows that the hypothesis $\mathrm{H} 3$ is accepted. Thus, it can be concluded that the variables of job satisfaction and work stress have a simultaneous or joint effect on turnover intention.

\section{CONCLUSSION}

Based on the analysis of the data above it can be concluded that: (1) Job satisfaction has significant effect on turnover intention employees of PT. Telkom Indonesia Yogyakarta. (2) Job stress has significant effect on turnover intention of employees of PT. Telkom Indonesia Yogyakarta. (3) Job satisfaction and Job stress jointly have significant effect on turnover intention of employees of PT. Telkom Indonesia Yogyakarta.

\section{ACKNOWLEDGMENTS}

The researchers would like to thank the Chancellor of UAD, dean of the Faculty of Economics and Business and colleagues who have provided suggestions on the results of this study. The researchers also extend gratefulness to the leaders of PT Telkom Indonesia Yogyakarta and their staff for their collaboration and contribution in this research.

\section{REFERENCE}

Dewi, Chadek Novi charisma, I Wayan Bagia, dan Gede Putu Agus Jana Susila. (2014). Pengaruh Stres Kerja dan Kepuasan Kerja Terhadap Kinerja Karyawan Pada Bagian Tenaga Penjualan UD Surya Raditya Negara.Jurnal Manajemen.1-9.

Dewi, K. Ayu Budi Astiti Purnama, dan I Made Artha Wibawa. (2016). Pengaruh Stres Kerja Pada Turnover Intention Yang Dimediasi Kepuasan Kerja Agen AJB Bumiputera 1912. Jurnal Manajemen. 1-26

Handoko, H. (2001). Manajemen Personalia dan Sumberdaya Manusia. Yogyakarta: BPFE Yogyakarta

Luthan S. (2006). Perilaku Organisasi. Edisi 10 Penerbit Andi Yogyakarta.

Martoyo, Susilo. (2007). Manajemen Sumber Daya Manusia. Ed. 5, Yogyakarta: BPFEYogyakarta.

Mas'ud F. (2002). 40 Mitos Manajemen Sumber Daya Manusia. Badan Penerbit Universitas Diponegoro Semarang.

Mobley. (1986). Pergantian Karyawan: Sebab-Akibat dan Pengendaliannya. Pustaka Binaman Pressindo.

Nelwan. (2008). Pengaruh Karakteristik Pekerjaan, Kepemimpinan Transformasional, Peluang promosi terhadap Kepuasan Kerja, Komitmen Organisasi dan Turnover Intention. Jurnal Manajemen. 5(2).

Rivai dan Dedi. (2012). Kepemimpinan dan Perilaku Organisasi. Edisi ketiga, PT. Raja Grafindo Persada. Jakarta

Sangadji, Etta Mamang, dan Sopiah. (2010). Metodologi Penelitian Pendekatan Prakts Dalam Penelitian. Yogyakarta: Andi Yogyakarta. 
Sugiyono. (2015). Metode Penelitian Kuantitatif, Kualitatif dan R\&D. Cetakan Keduapuluh tiga. Bandung: Alfabeta.

Syahronica, Gabriela, Moehammad Soe'oed Hakam, dan Ika Ruhana. (2015). Pengaruh Kepuasan Kerja Dan Stres Kerja Terhadap Turnover Intention Studi Pada Karyawan Departemen Dunia Fantasi Pt. Pembangunan Jaya Ancol, Tbk. Jurnal Administrasi Bisnis.1-6.

Waspodo, Agung AWS, Nurul Chotimah Handayani, dan Widya Paramitha. (2013). Pengaruh Kepuasan Kerja Dan Stres Kerja Terhadap Turnover Intention Pada Karyawan PT. Unitex Bogor. Jurnal Riset Manajemen Sains Indonesia. 1-19. 